Voix et Images

volxetimages

\title{
Erratum : Vol. 13, no 2, hiver 1988
}

Volume 13, numéro 3 (39), printemps 1988

Jack Kerouac et l’imaginaire québécois

URI : https://id.erudit.org/iderudit/013679ar

DOI : https://doi.org/10.7202/013679ar

Aller au sommaire du numéro

Éditeur(s)

Université du Québec à Montréal

ISSN

0318-9201 (imprimé)

1705-933X (numérique)

Découvrir la revue

Citer ce document

(1988). Erratum : Vol. 13, no 2, hiver 1988. Voix et Images, 13(3), 520-520.

https://doi.org/10.7202/013679ar d'utilisation que vous pouvez consulter en ligne.

https://apropos.erudit.org/fr/usagers/politique-dutilisation/ 


\section{ERRATUM}

Une erreur s'est malencontreusement glissée lors du montage du numéro 38 de Voix \& images. Les deux derniers paragraphes de la chronique de Lucie Robert sont manquants. Ils sont reproduits ici. Nos excuses a l'auteure.

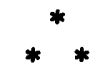

L'histoire repose sur les épaules d'une bande d'adolescents et d'adolescentes qui se prennent pour des rockers alors qu'ils et elles adoptent des noms à l'américaine (Popstar, Shortcake, Bunny), qu'ils et elles jouent aux petits voleurs en chipant n'importe quoi, sans connaître la valeur de revente, et qui croient chanter en se contentant de doubler au lipsing les grands succès de leur héros (leur oncle d'Amérique pourrait-on dire), les Dickers de Los Angeles. Pour tout dire, la pièce ressemble à une sorte de remake de Zone, dont on aurait enlevé la dimension tragique. L'agent Boudreault, en effet, surveille discrètement la bande, arrêtant le receleur (la Guêpe) quand le vol devient trop sérieux, protégeant les jeunes des autres policiers plus sévères, et camouflant au besoin ce que la bande ne considère que comme des incartades.

Les personnages, en effet, jouent les héros qu'ils et elles ne sont pas. Il ne vient à personne l'idée de faire de la vraie musique, ni de voler des objets utiles ou revendables, du moins jusqu'à l'arrivée de Bunny qui veut devenir chanteuse et qui tente de transformer ses rêves en carrière comme Judith l'avait fait avant elle, détruisant ainsi à la fois l'orgueil et l'amour du (faux-) Bourdon. Désespéré, celuici n'a plus qu'un but: amasser l'argent nécessaire au pèlerinage à Los Angeles pour voir et entendre en personne ses héros, quitte à se prostituer pour y arriver, Frasque qui, comme celle des autres, sera rattrapée, si l'on peut dire, par une agente de police devenue ange gardien et qui empêche Bourdon, Bunny, Popstar, Judith, Shortcake et Larry d'atteindre la profondeur des premiers héros de Marcel Dubé. Le vidéoclip, en effet, n'admet pas de fin tragique. Comme par certains vidéos, pourtant, on se laisse séduire.

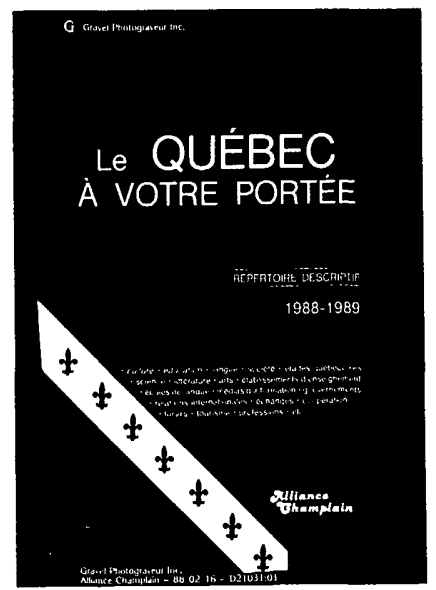

